\title{
PENGARUH PERILAKU BERFOTO DI OBYEK WISATA TERHADAP KEBAHAGIAAN WISATAWAN
}

\author{
Saptin Dwi Setyo Hastuti, M.Pd \\ NIDN. 0527048702 \\ Dosen Sekolah Tinggi Pariwisata AMPTA Yogyakarta \\ e-mail : saptin27@gmail.com
}

\begin{abstract}
In these recent years, the prospect of photography is increasing. It also influences tourism industry. Photography also has important role in the development of tourism industry. This research aims to investigate (1) the factors influencing tourist's behavior in taking photo, (2) the activities after taking photo, (3) and the influence of tourist's behavior in taking photo towards their happiness.

This research was a survey research. The locations of this research were in Malioboro, Hutan Pinus, Tebing Breksi, Kalibiru, and Gunung Api Purba Nglanggeran. The population comprised the visitors of those places. The sample was taken by applying sample non probability technique due to the unavailable visit data. The sample for each place was 80 . Thus, the whole sample was 400. The survey was conducted on April - May 2017. The data were collected through questionnaire. The data were analysed by applying descriptive statistics and crosstab in the SPSS 16.

The result of the research shows that the factors influencing the tourists' photo behavior are the scenery or background of the place, the condition and completeness of facilities, the provided photo spot, the photo activity, and the access post photo. Furthermore, the result also shows that the activities after taking photo were the speed of publishing the photo, the editing, dan publishing photo in instagram. Last, the tourist's taking photo behavior influencing the happiness were because of the reason of taking photo, taking photo at different spot, taking many photos, and the quality of the photo.
\end{abstract}

Keywords : :Tourism, Photo, Happiness

\section{PENDAHULUAN}

Dalam beberapa tahun terakhir, aspek fotografi tidak dapat dipisahkan dari industri pariwisata (Urry dan Larsen, 2011). Fotografi dapat menghubungkan objek wisata dengan memori wisatawan pada saat mengunjungi objek wisata. Istilah yang berkembang bagi para wisatawan sekarang ini adalah " $n o$ pictute hoax", tidak ada gambar berarti bohong. Foto merupakan bukti yang bisa dan biasa diberikan wisatawan untuk menggambarkan pengalaman mereka mengunjungi suatu objek wisata (Ntarangwi, 2000).
Perkembangan Information Communication Technology (ICT) di era globalisasi ini memberikan andil yang besar bagi peradaban umat manusia. Dengan kehadiran ICT, wisatawan dapat langsung berbagi pengalaman berwisata dengan keluarga dan sahabat di rumah melalui media sosial seperti facebook, twitter, Path, instagram, blog, web, dan sejenisnya. Beberapa peneliti menemukan kaitan antara perilaku berfoto wisatawan di obyek wisata akan mempengaruhi kebahagiaan wisatawan. Foto-foto akan menawarkan bukti tak terbantahkan bahwa perjalanan 
wisatawan telah dilakukan dan sangat menyenangkan (Haldrup dan Larsen, 2003).

Setiap kali saya melihat sesuatu yang indah, aneh atau sekadar membingungkan selama perjalanan, saya harus memotret itu. Saya suka mengambil foto selama fotografi perjalanan saya ke luar negeri. Berwisata adalah hobi indah yang memberikan penghargaan anda dengan gambar yang merangkum kenangan untuk seumur hidup. Saya senang ketika diri saya membawa pulang ratusan (bahkan ribuan) foto hasil berwisata pada kartu SD (memory card) saya. (Kassim Qureshi, 2010 dalam Gillet, $d k k, 2016)$.

Pengalaman seorang Kassim Qureshi diatas tidak mengherankan karena fotografi yang merupakan elemen penting dalam kegiatan- kegiatan yang mendefinisikan pengalaman seseorang akan pariwisata. Apa yang diceritakan Kassim Qureshi menunjukkan bahwa kebahagiaan seseorang berasal dari perilaku berfoto, dan perilaku berfoto ini harus sering didorong untuk meningkatkan kenikmatan sebuah proses liburan (Fredrickson, 2001 dalam Gillet, dkk, 2016).

Saat ini, di Daerah Istimewa Yogyakarta banyak bermunculan objek wisata baru yang digemari akibat dari beredarnya foto-foto objek tersebut di dunia maya. Foto-foto yang beredar di internet awal mulanya berasal dari pengelola yang mengenalkan potensi objek yang dimiliki. Sekarang, banyak foto objek wisata baru yang diunggah oleh wisatawan dan langsung menjadi viral di internet. Lokasi obyek wisata yang dijadikan bahan studi adalah Wisata Alam Kalibiru, Gunung Api Purba Nglanggeran, Tebing Breksi, Hutan Pinus Imogiri, dan Malioboro. Dengan adanya fenomena tersebut, penelitian ini bertujuan untuk menggali faktor-factor yang mempengaruhi perilaku berfoto, hal yang dilakukan wisatawan setelah berfoto, dan pengaruh perilaku berfoto terhadap kebahagiaan wisatawan.

\section{LITERATURE REVIEW \\ Pariwisata}

Pariwisata adalah berbagai macam kegiatan wisata yang didukung dengan berbagai fasilitas serta layanan yang disediakan oleh masyarakat, pengusaha, pemerintah, dan pemerintah daerah. Sedangkan wisata adalah kegiatan perjalanan yang dilakukan oleh seseorang atau sekelompok orang dengan mengunjungi tempat tertentu untuk tujuan rekreasi, pengembangan pribadi, atau mempelajari keunikan daya tarik wisata yang dikunjungi dalam jangka waktu sementara (UndangUndang Republik Indonesia No.10 tahun 2009).

Fandeli (1995) mendefinisikan pariwisata adalah keseluruhan kegiatan, proses, dan kegiatan-kegiatan yang berhubungan dengan perjalanan dan persinggahan dari orang-orang luar tempat tinggalnya serta tidak bermaksud mencari nafkah. Suatu perjalanan dianggap sebagai perjalanan wisata bila memenuhi tiga syarat yaitu: 1) harus bersifat sementara; 2) harus bersifat sukarela (voluntary) dalam arti tidak terjadi karena dipaksa, 3) tidak bekerja yang sifatnya menghasilkan upah ataubayaran.

Beberapa ahli berpendapat bahwa pariwisata merupakan suatu perjalanan yang dilakukan secara perorangan atau berkelompok dari suatu tempat ke tempat lain yang bersifat sementara dan bertujuan untuk mendapatkan kesenangan (leisure). Fennel (1999) seperti dikutip dalam Pitana (2009) mendefinisisikan bahwa pariwisata merupakan system yang saling terkait antara wisatawan dan pelayanan wisata disediakan dan digunakan (fasilitas, atraksi dan tranportasi dan akomodasi) untuk mengakomodir kegiatan wisata. 
Dengan demikian dapat disimpulkan bahwa pariwisata merupakan sebuah pergerakan yang dilakukan oleh perorangan maupun kelompok dari suatu daerah ke daerah lain bersifat sementara yang bertujuan untuk rekreasi dan bukan untuk tujuan bekerja. Selain itu berwisata sejatinya bertujuan untuk keluar dari rutinitas seharihari untuk mencari perbedaan ditempat lain serta mencari kesenangan (leisure) dengan menikmati produk wisata yang ditawarkan di tempat tujuan wisata.

\section{Pariwisata dan Kebahagiaan Wisatawan}

Menurut Lyubomirsky, Sheldon, et al. (2005), $50 \%$ kebahagiaan seseorang diperoleh melalui proses individu masing-masing orang. Keadaan kehidupan seseorang individu (tempat tinggal, usia, faktor dari sejarah pribad iindividu), memberikan sumbangan sekitar $10 \%$ dari kebahagiaan manusia. Sisanya $40 \%$ yang menentukan kebahagiaan seseorang terkait dengan kegiatan dan praktek secara sukarela dipilih. Dalam konteks ini, praktik fotografi yangdilakukandi obyek wisata dianggap di antara kegiatan ini secara sukarela dipilih (Lyubomirsky, Sheldon, etal).

Literatur mengenai fotografi wisatawan sebagai titik awal untuk melihat sejumlah item untuk mengukur perilaku berfoto wisatawandi obyekwisata. Frekuensi berfoto, pemilihan frame/angle foto, masing-masing memiliki pengaruh yang yang relatif berbeda satu wisatawan dengan wisatawan yang lain. Dengan demikian hal tersebut dinilai penting untuk mengetahui frekuensi berfoto wisatawandan pemilihan frame/angle foto ketika berwisata.

\section{Fotografi dan Kebahagiaan Wisatawan}

Perilaku berfoto wisatawan di obyek wisata dimulai setelah mereka menemukan lokasi yang cocok untuk mengambil foto. Setelah itu, kemudian para wisatawan memilih bagimana sudut/angle kamera terbaik dengan atau tanpa seseorang diposisikan di depan kamera. Mereka kemudian membuat satu atau beberapa foto. Akhirnya, mereka akan mengecek di layar kamera untuk melihat apakah gambar yang dihasilkan akan memuaskan atau tidak. Para wisatawan kemudian akan biasanya kembali ke tahap awal (mencari lokasi yang lainuntuk berfoto) atau fasekomposisi (menyesuaikan sudut untuk meningkatkan foto) apabila mendapatkan hasil yang kurang memuaskan pada percobaan yang bertama.

Fenomena yang sekarang ini terjadi yakni sejumlah wisatawan mengambil sangat banyak gambar karena sekarangini dengan kecanggihan dan kemudahan dalam berfoto sangat memungkinkan untuk menilai apakah kualitas fotoyang dihasilkan akan bagus atau tidak. Jika bagus tentu akan memuaskan dan jika tidakmakatinggal menghapus atau coba ambir gambarlagi.

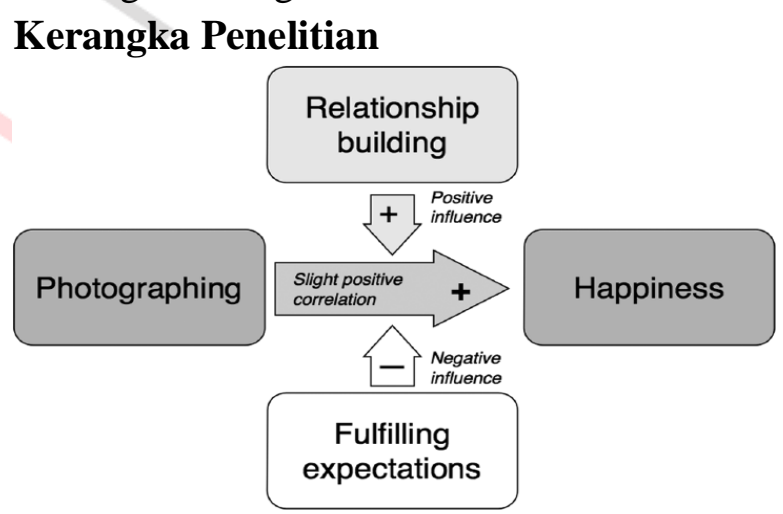

Gambar 2.1. Kerangka dasar penelitian (Sumber: Gillet, dkk, 2016.)

\section{METODOLOGI PENELITIAN}

\section{Jenis Penelitian}

Penelitian ini merupakan penelitian survei. Penelitian survei digunakan untuk mendapat data yang terjadi pada masa lampau maupun saat ini, dimana tidak ada perubahan dan atau perlakuan khusus terhadap variabel yang diteliti. Data yang dikumpulkan terkait dengan keyakinan, pendapat, karakteristik, perilaku, hubungan 
variabel dan untuk menguji beberapa hipotesis tentang variabel sosiologis dan psikologis dari sampel yang diambil dari populasi tertentu, teknik pengumpulan data dengan pengamatan (wawancara atau kuesioner) dan hasil penelitian cenderung untuk digeneralisasikan (Hasan, 2002; Sugiyono, 2013).

\section{Lokasi Penelitian}

Penelitian ini dilakukan di lima obyek wisata yang ada di Yogyakarta. Kelima obyek wisata tersebut terletak di lima kabupaten di Yogyakarta. Obyek wisata yang pertama adalah Wisata Alam Kalibiru yang terletak di kabupaten Kulon Progo. Kedua adalah Gunung Api Purba Nglanggeran yang terletak di Gunung Kidul. Ketiga adalah Kawasan Karts Tebing Breksi yang terletak di Sleman. Keempat adalah di Hutan Pinus Imogiri yang terletak di Bantul. Terakhir adalah Malioboro yang terletak di Kota Yogyakarta.

\section{Teknik dan Alat Pengumpulan Data}

Data yang dikumpulkan pada penelitian ini adalah data primer dan data sekunder. Data primer diambil langsung di lokasi penelitian dengan cara menyebarkan angket/kuisioner.

\section{Populasi dan Sampel}

Populasi dari penelitian ini adalah para pengunjung di kelima obyek wisata. Populasi dalam penelitian ini tidak dapat diketahui dengan pasti dikarenakan di tiga obyek wisata (Malioboro, Kawasan Karst Tebing Breksi, dan Hutan Pinus Imogiri) tidak memiliki data kunjungan wisatawan. Sedangkan dua lainnya mempunyai data kunjungan wisatawan yang lengkap. Sampel diambil dengan menggunakan teknik sample non probability dimana tidak memberikan peluang yang sama bagi populasi (pengunjung) untuk dipilih. Sampel yang digunakan dalam penelitian ini sejumlah 400 wisatawanyang dibagi ke lima obyek wisata, sehingga 1 obyek wisata sama dengan 80 responden.

\section{HASIL PENELITIAN DAN PEMBAHASAN}

\section{Karakteristik Pengunjung}

Dari hasil penelitian, dapat disimpulkan bahwa di kelima obyek wisata ini terkenal dikalangan anak muda umumnya adalah pelajar/mahasiswa dan pegawai swasta. Hal ini dapat dibuktikan dengan dominasi pengunjung yang berusia antara 18 - 30 tahun yaitu $80 \%$ dan pengunjung yang berprofesi pelajar/mahasiswa $(46.5 \%)$ dan pegawai swasta $(20.2 \%)$. Hasil tersebut dapat dilihat pada tabel 1.

Selanjutnya, kelima obyek wisata ini juga terkenal di luar kota Yogyakarta. Hal ini ditunjukkan dari hasil penelitian bahwa $65.2 \%$ dari keseluruhan pengunjung berasal dari luar kota. Sedangkan $34.8 \%$ dari pengunjung berasal dari dalam kota. Hal ini tidak serta merta berarti bahwa kelima obyek wisata tersebut tidak terkenal di dalam kota Yogyakarta. Hal tersebut berarti kelima obyek wisata tersebut menjadi daya tarik tersendiri bagi pawa wisatawan dari berbagai daerah. Dari 400 pengunjung, terdapat $43.6 \%$ yang baru satu kali mendatangi tempattempat wisata tersebut. Diluar dari $43.6 \%$ pengunjung telah melakukan lebih dari satu kali kunjungan. Hal ini dapat diartikan bahwa kelima obyek wisata tersebut mampu membuat para wisatawan yang berkunjung tersebut kembali mengunjungi tempat tersebut. Hasil tersebut dapat dilihat pada tabel 2 .

\section{Faktor - faktor yang Mempengaruhi Perilaku Berfoto}

Motivasi dalam berfoto dapat dipengaruhi oleh factor internal maupun eksternal. Dalam penelitian ini, faktor motivasi yang diteliti adalah motivasi 
eksternal dalam kaitannya dengan keberadaan fasilitas maupun aksesibilitas di obyek wisata.

Pada dasarnya keadaan lingkungan ataupun pemandangan alam di obyek wisata adalah menjadi motivasi utama dalam kegiatan berfoto para pengunjung obyek wisata. Hal ini ditunjukkan dengan data hasil penelitian bahwa sebanyak $79.9 \%$ pengunjung menyatakan mereka tertarik untuk berfoto di kelima obyek wisata karena keadaan lingkungan ataupun pemandangan alam di obyek wisata tersebut. Mayoritas yang menyatakan bahwa keadaan lingkungan atau pemandangan alam menjadi factor untuk berfoto adalah kalangan anak muda berusia antara 18 - 30 tahun dengan besaran 67. 3\%. Hasil tersebut dapat dilihat pada tabel 3.

Selain keadaan lingkungan atau pemandangan alam di obyek wisata, motivasi lain yang mempengaruhi pengunjung unruk berfoto adalah lengkapnya fasilitas berfoto dan kondisi dari fasilitas tersebut. Mayoritas dari pengunjung, yaitu sebesar $73.1 \%$, menyatakan bahwa kelengkapan fasilitas berfoto dan kondisi dari fasilitas tersebut menjadikan salah satu motivasi berfoto di obyek wisata. Salah satu fasilitas yang disediakan oleh pengelola obyek wisata adalah nama obyek wisata ataupun spot spot foto yang dibentuk sedemikian rupa sehingga dapat dijadikan tempat berfoto. Hasil tersebut dapat dilihat pada tabel 4.

Lebih jauh lagi, kemudahan pada saat menemukan lokasi yang menarik untuk berfoto dapat mempengaruhi kepuasan pengunjung pada saat mengunjungi obyek wisata. Dari hasil penelitian, dapat diketahui bahwa secara keseluruhan lokasi untuk berfoto dapat dengan mudah ditemukan. Hal tersebut terubukti bahwa $86.3 \%$ dari pengunjung menyatakan bahwa kemudahan dalam menemukan lokasi berfoto dapat mempengaruhi kepuasan mereka yang nantinya berimbas pada perilaku berfoto. Hasil tersebut dapat dilihat pada tabel 5.

Selain factor - factor tersebut di atas, aksesibilitas dalam hal ini adalah kemudahan akses internet juga dapat mempengaruhi motivasi pengunjung dalam berfoto. Dalam artian pengunjung dapat langsung mem publish foto yang mereka dapatkan pada saat di obyek wisata. Dari hasil penelitian, didapatkan bahwa $63.3 \%$ jawaban menyatakan bahwa aksesibilitas terhadap internet sudah cukup memadai. Walaupun aksesibilitas terhadap internet sudah cukup memadai, aksesibilitas tersebut perlu untuk ditingkatkan kembali. Hal ini dikarenakan internet sudah menjadi sebuah kebutuhan bagi manusia, terutama anak muda. Hasil tersebut dapat dilihat pada tabel 6 .

\section{Aktifitas yang Dilakukan Wisatawan Setelah Berfoto}

Aktifitas yang dilakukan wisatawan setelah mendapatkan foto menjadi sebuah indicator perilaku dalam berfoto. Perilaku yang ditunjukkan wisatawan setelah mendapatkan foto antara lain edit foto, publish foto, dan publish foto di media sosial. Perilaku wisatawan setelah mendapatkan foto adalah proses edit foto. Hampir separuh dari pengunjung menjawab bahwa mereka melakukan edit foto sebelum di unggah di media social. Dari pengunjung tersebut didominasi oleh kalangan muda sebanyak 53.7\%. Hasil tersebut dapat dilihat pada tabel 7.

Perilaku dalam mem-publish foto di media social juga dapat dijadikan indicator tingkat kepuasan dalam berfoto. Sebesar $64.8 \%$ menyatakan bahwa foto yang telah didapatkan langsung di publish di media social. Dari mayoritas wisatawantersebut, sebanyak $54.5 \%$ berada di rentang umur 18 30 tahun. Sedangkan selebihnya berada direntang umur dibawah 17 tahun yaitu 
sebanyak 27 orang atau $6.8 \%$ dan direntang umur 31 - 56 tahun yaitu sebanyak 11 orang atau $2.8 \%$. Hasil tersebut dapat dilihat tabel 8.

Saat ini, social media yang dapat digunakan sebagai media publish foto sangat beragam. Dari berbagai macam social media tersebut, instragram merupakan salah satu platform atau aplikasi yang dikhususkan sebagai media menyebarkan foto ataupun video. Mayoritas jawaban wisatawan menyatakan bahwa instagram merupakan media utama untuk mem-publish foto. Hal tersebut ditunjukkan besaran angka 313 orang atau $78.3 \%$. Dari angka tersebut, mayoritas wisatawanyang menggunakan instagram berumur 18 - 30 tahun dengan besaran angka $66.8 \%$ atau 267 orang. Hasil tersebut dapat dilihat pada tabel 9.

\section{Pengaruh Perilaku Berfoto terhadap Kebahagiaan Wisatawan}

Salah satu tujuan dari penelitian ini adalah untuk melihat pengaruh perilaku berfoto terhadap kebahagiaan wisatawan. Melalui data-data hasil survey yang sudah dianalisis maka pengaruh perilaku berfoto terhadap kebahagiaan wisatawan dapat diketahui. Ada berbagai macam motif alasan berfoto dalam perilaku berfoto dan publish bagi wisatawan. Alasan-alasan tersebut dapat menjadi representasi dari kebahagiaan. Alasan-alasan tersebut antara lain:

a. Ingin Mendapatkan Kenangan

Berharga. Sebanyak 150 orang atau $37.5 \%$ menyatakan keinginan untuk menda-patakan kenangan yang berharga saat berfoto. Dari angka tersebut, wisatawan yang menjawab mayoritas berada pada rentang umur 18 - 30 tahun yaitu sebanyak 125 orang atau $31.3 \%$. Selebihnya berada pada rentang umur di bawah 17 tahun dan 31-56 tahun.

\section{b. Ingin Mengabadikan Keindahan}

Alam. Sebanyak 193 orang atau $48.3 \%$ menyatakan keinginan untuk mengabadikan keindahan alam. Dari angka tersebut, wisatawan yang menjawab mayoritas berada pada rentang umur 18 - 30 tahun yaitu sebanyak 164 orang atau $41 \%$.Selebihnya berada pada rentang umur di bawah 17 tahun dan 31-56 tahun.

c. Ingin Pamer kepada Orang Lain. Sebanyak 29 orang atau $7.3 \%$. Selanjut-nya, wisatawan yang menyatakan keinginan untuk memperoleh pujian atau sanjungan dari orang lain hanya sebanyak 28 orang atau $7 \%$ (tabel 10).

Sebuah obyek wisata yang mem-punyai banyak spot menarik yang dapat digunakan sebagai spot foto juga akan dapat memberikan efek bahagia kepada wisatawan. Hal tersebut disebabkan karena wisatawan mendapatkan variasi background dalam berfoto. Separuh lebih wisatawan menyatakan bahwa banyaknya spot foto di obyek wisata dapat mempengaruhi kebahagiaan. Hal tersebut dapat ditunjukkan dengan besaran angka sebesar $83.5 \%$ atau sebanyak 334 orang. Dari angka tersebut, wisatawan yang menyatakan bahwa banyaknya spot foto mempengaruhi kebahagiaan berada di rentang umur 18 - 30 tahun yaitu sebanyak 279 orang atau $69.8 \%$. Hasil tersebut dapat dilihat pada tabel 11 .

Selain banyaknya obyek wisata, aktifitas berfoto sendiri juga dapat memberikan rasa bahagia pada wisatawan. Mayoritas dari responden, yaitu sebanyak 337 orang atau $84.3 \%$, menyatakan bahwa aktifitas berfoto merupakan aktifitas yang paling menarik pada saat berada di obyek wisata. Mayoritas wisatawan yang menyatakan bahwa aktifitas berfoto merupakan 
aktifitas yang menarik berada pada rentang umur 18 - 30 tahun. Selebihnya adalah wisatawan pada rentang umur di bawah 17 tahun sebanyak 32 orang atau $8 \%$ dan pada rentang umur 31-56 tahun sebanyak 26 orang atau $6.5 \%$. Hasil tersebut dapat dilihat pada tabel 12.

Selanjutnya, untuk mendapatkan foto yang terbaik maka harus mengambil foto berkalil-kali. Hal ini juga mungkin mempengaruhi tingkat kebahagiaan wisatawan. mayoritas wisatawan menyatakan bahwa untuk mendapatkan foto diperlukan pengambilan foto berkali kali.Hal tersebut dapat ditunjukkan melalui besaran angka sebesar $88 \%$ atau 352 orang. Dari mayoritas wisatawanyang menjawab, sebanyak 290 orang atau $72.5 \%$ berada pada rentang usia 18 - 30 tahun. Selebihnya, sebanyak 24 orang atau $8.5 \%$ berada pada rentang di bawah 17 tahun dan sebanyak 28 orang atau $7 \%$ berada pada rentang di 31-56 tahun. Hasil tersebut dapat dilihat pada tabel 13.

Kuantitas foto yang didapatkan juga dapat menentukan tingkat kebahagiaan wisatawan. mayoritas responden, yaitu sebanyak 337 orang atau $84.3 \%$, menyatakan kuantitas foto yang diambil menentukan perasaan bahagia. Dari jumlah tersebut, mayoritas berada pada rentang umur 18-30 tahun yaitu sebanyak 280 orang atau $70 \%$. Selebihnya, pada rentang umur di bawah 17 tahun adalah sebanyak 32 orang atau $8 \%$ dan pada rentang umur $31-56$ adalah sebanyak 25 orang atau $6.3 \%$. Hasil tersebut dapat dilihat pada tabel 14 .

Selain kuantitas foto yang diambil, tentu kualitas foto yang diambil juga memberikan pengaruh terhadp tingkat kebahagiaan wisatawan. mayoritas responden, yaitu sebanyak 363 orang atau 90.8\%, menyatakan kualitas foto yang diambil menentukan perasaan bahagia. Dari jumlah tersebut, mayoritas berada pada rentang umur
18-30 tahun yaitu sebanyak 306 orang atau $76.5 \%$. Selebihnya, pada rentang umur di bawah 17 tahun adalah sebanyak 32 orang atau $8 \%$ dan pada rentang umur $31-56$ adalah sebanyak 25 orang atau $6.3 \%$. Hasil tersebut dapat dilihat pada tabel 15 .

\section{KESIMPULAN DAN REKOMENDASI Kesimpulan}

Secara keseluruhan penelitian ini dapat disimpulkan sebagai berikut :

\section{Faktor - faktor yang mempengaruhi perilaku berfoto}

Motivasi merupakan salah satu faktor yang mempengaruhi perilaku berfoto, terutama motivasi yang dipengaruhi oleh kondisi lingkungan obyek wisata (eksternal).

a. Di kelima obyek wisata, pemandangan alam merupakan obyek yang menarik bagi wisatawan terutama wisatawan yang berumur di antara 18 - 30 tahun atau kaum muda.

b. Kondisi dan kelengkapan fasilitas berfoto juga menjadikan faktor penentu perilaku berfoto. Di kelima obyek wisata, kondisi dan kelengkapan fasilitas yang menarik untuk berfoto bagi wisatawan terutama kaum muda untuk berfoto.

c. Selain kedua hal tersebut di atas, spot foto yang disediakan juga menarik kaum muda untuk berfoto.

Selain kondisi lingkungan obyek wisata, motivasi perilaku berfoto juga ditunjukkan dari kegiatan atau aktifitas berfoto itu sendiri.

a. Di kelima obyek wisata, wisatawan dapat melakukan banyak aktifitas berfoto, terutama kaum muda.

b. Kemudahan akses juga menjadi salah satu motivasi berfoto para wisatawan. Di kelima obyek wisata, wisatawan mendapatkan kemudahan dalam 
mendapatkan lokasi berfoto dan hal tersebut mempengaruhi tingkat kepuasan berfoto, terutama kaum muda.

c. Kemudahan akses pasca berfoto juga merupakan salah satu faktor yang mempengaruhi perilaku berfoto.

2. Hal yang dilakukan wisatawan setelah berfoto

a. Kebanyakan wisatawan, setelah mendapatkan foto, mereka lansung mem-publish di media social. Hal tersebut dilakukan oleh kaum muda.

b. Kegiatan publish foto tersebut melalui tahapan edit foto. Sehingga, wisatawan akan mengambil banyak gambar kemudidan mengedit gambar tersebut kemudia akan di publish di media social. Hal tersebut dilakukan untuk mendapatkan kepuasan dan utamanya dilakukan oleh kaum muda.

c. Dewasa ini, media social yang sedang popular diantar kaum muda adalah instagram. Platform atau aplikasi ini memudahkan wisatawan yang senang berfoto dan ingin mempublikasikan kepada khalayak umum. Kebanyakan pemakai media social instagram ini adalah kaum muda.

3. Pengaruh perilaku berfoto terhadap kebahagiaan wisatawan

a. Alasan utama wisatawan dalam berfoto adalah untuk mendapat kenangan berharga dan ingin mengabadikan keindahan alam.

b. Banyaknya spot foto yang tersedia di kelima obyek wisata juga membuat wisatawan bahagia.

c. Banyaknya aktifitas berfoto yang dapat dilakukan di kelima obyek wisata tersebut juga dapat menimbulkan perasaan bahagia bagi wisatawan.

d. Pengambilan foto yang berkali-kali membuat wisatawan merasa bahagia. e. Kualitas dan kuantitas foto yang diambil juga menentukan perasaan bahagia wisatawan.

\section{Rekomendasi}

Melihat hasil dari penelitian maka bagi para pengelola obyek wisata dapat melakukan hal dibawah ini guna dapat menarik lebih banyak wisatawan ke obyek wisata.

1. Melestarikan atau menjaga keindahan alam dan fasilitas di obyek wisata karena motivasi utama para wisatawan dalam berfoto adalah adanya pemandangan alam atau tempat yang indah serta fasilitas yang baik dan memadai.

2. Memberikan kemudahan akses internet karena motivasi utama dalam berfoto adalah mempublish foto yang mereka dapatkan ke media social, terutama instagram.

3. Menyediakan spot foto buatan dikarenakan spot foto merupakan daya tarik tersendiri bagi wisatawan.

4. Mendukung wisatawan dalam berfoto akan menimbulkan perasaan bahagia bagi wisatawan yang akan berdampak positif bagi obyek wisata.

\section{Keterbatasan dan Penelitian Mendatang}

Daerah Istimewa Yogyakarta (DIY) mempunyai banyak sekali obyek wisata yang terdapat banyak sekali pengunjung. Namun, karena terbatasnya tenaga dan waktu peneliti maka dalam penelitian ini hanya melibatkan lima obyek wisata di lima kabupaten di DIY.

Lebih lanjut, populasi dalam penelitian ini tidak dapat diketahui dengan pasti dikarenakan obyek-obyek wisata tersebut belum memiliki dokumentasi kunjungan wisatawan. Hal tersebut mengakibatkan jumlah safe sample tidak dapat diketahui, dengan demikian kemungkinan yang terjadi adalah tidak terwakilinya populasi. 
Selanjutnya, penelitian ini dapat dijadikan dasar pada penelitian berikutnya dengan melibatkan lebih banyak obyek wisata di Daerah Istimewa Yogyakarta. Hal tersebut dimaksudkan agar dapat memberikan rekomendasi kepada pengelola obyek wisata di DIY untuk meningkatkan kunjungan wisata di obyek-obyek wisata.

\section{DAFTAR PUSTAKA}

Arikunto, S., 2002, Prosedur Suatu Penelitian: Pendekatan Praktek , Jakarta: Rineka Cipta.

Creswell, J. W., 2010, Research Design Pendekatan Kualitatif, Kuantitatif, dan Mixed, Yogyakarta: Pustaka Pelajar.

Fandeli, C. 1995. Dasar-Dasar Manajemen Kepariwisataan Alam. Yogyakarta: Penerbit Liberty.

Fennel, David A. 1999.Ecotourism, An Introduction. New York: Routledge.

Ghozali, I. H., 2006, Aplikasi Analisis Mutivariate Dengan Program SPSS, Semarang: Badan Penerbit Univeritas Diponegoro.

Gillet, Sarah, Paulina Schmitz, dkk, 2016.Journal of Hospitality \&Tourism Research, Vol. 40, No. 1, January 2016, 37-57. NHTV BredaUniversity.

Haldrup, M., and Larsen, J., 2003, The Family Gaze, Tourist Studies, 3: 2345.

Hasan, M. I., 2002, Pokok-Pokok Materi Metodologi Penelitian dan Aplikasinya, Bogor: Ghalia Indonesia. Kusmayadi, dan Sugiarto, E., 2000, Metodologi Penelitian DalamBidang Pariwisata, Jakarta: Gramedia Pustaka Utama.

Lyubomirsky, S., King, L., \&Diener, E. (2005).The benefits of frequent positive affect: Does happiness lead to success? Psychological Bulletin, $131,803-855$.

Masruri, N.W., 2014, Studi Pengembangan Objek Daya Tarik Wisata Kawasan Ekowisata Gunung Api Purba Nglanggeran Kabupaten Gunung Kidul, DIY, Tesis: Universitas GadjahMada.

Ntarangwi, Mwenda, 2000, Education, Tourism, or Just a Visit to theWild?, African Issues, 28 (1/2):54-60.

Pitana, I.G. dan Diarta, K.S. 2009.Pengantar Ilmu Pariwisata. Yogyakarta: CV. Andi Offset.

Prideaux, B., and Coghlan, A., 2010, "DigitalCameras and Photo Taking Behaviour on the Great Barrier Reef - Marketing Opportunities for Reef Tour Operators", Journal of Vacation Marketing, 16:171-183.

Rahayu, Handayani. 2015, Studi Eksplorasi Perilaku Wisatawan dalam Berfoto di Gunung Api Purba Nglanggeran Kabupaten Gunung Kidul, DIY, Tesis: Universitas Gadjah Mada.

Sheungting Lo, I., McKercher, B., Cheung, C., Law., R, 2011, Tourism and Online Photography, Tourism Management, 32: 725-731.

Sugiyono, 2008, Metode Penelitian Pendidikan: Pendekatan Kuantitatif, Kualitatif, dan $R \& D$, Bandung:Alfabeta.

Sugiyono, 2013, Cara Mudah Menyusun: Skripsi, Tesis, dan Disertasi, Bandung: Alfabeta.

Undang-Undang Republik Indonesia No.10 tahun 2009.

Urry, J. and Larsen, J., 2011, The Tourist Gaze 3.0, London: SAGE Publications. 
Tabel 1. Distribusi Pengunjung berdasarkan Pendidikan dan Pekerjaan

\begin{tabular}{|l|l|l|}
\hline \multicolumn{1}{|c|}{ Distribusi Sampel } & \multicolumn{2}{c|}{ Frekuensi } \\
\hline Pendidikan & 3 & $0.8 \%$ \\
\hline SD & 38 & $9.5 \%$ \\
\hline SMP & 201 & $50.2 \%$ \\
\hline SMA & 57 & $14.2 \%$ \\
\hline D3 & 90 & $22.5 \%$ \\
\hline S1 & 10 & $2.5 \%$ \\
\hline S2 & 1 & $0.2 \%$ \\
\hline S3 & & \\
\hline Pekerjaan & 14 & $3.5 \%$ \\
\hline PNS & 186 & $46.5 \%$ \\
\hline Pelajar/Mahasiswa & 81 & $20.2 \%$ \\
\hline Pegawai swasta & 4 & $1 \%$ \\
\hline Pensiunan & 37 & $9.2 \%$ \\
\hline Wiraswasta & 54 & $13.5 \%$ \\
\hline Belum bekerja & 24 & $6 \%$ \\
\hline Lain-lain & & \\
\hline
\end{tabular}

Tabel 2. Distribusi Responden Berdasarkan Asal Daerah dan Frekuensi Kunjungan

\begin{tabular}{|c|c|c|c|c|c|}
\hline Distribusi Sampel & \multicolumn{2}{|c|}{ Frekuensi } & \multicolumn{3}{|c|}{ Persentase } \\
\hline Dalam Kota & \multicolumn{2}{|c|}{139} & \multicolumn{3}{|c|}{$34.8 \%$} \\
\hline Luar Kota & \multicolumn{2}{|c|}{261} & \multicolumn{3}{|c|}{$65.2 \%$} \\
\hline Nama Obyek Wisata & 1kali & 2 Kali & 3 kali & 4 Kali & $>4$ Kali \\
\hline Malioboro & $3.75 \%$ & $4.5 \%$ & $2.8 \%$ & $1.8 \%$ & $7.3 \%$ \\
\hline Hutan Pinus & $10 \%$ & $4.5 \%$ & $3 \%$ & $0.8 \%$ & $1.8 \%$ \\
\hline Kalibiru & $4 \%$ & $10.8 \%$ & $4 \%$ & $0.8 \%$ & $0.5 \%$ \\
\hline Tebing Breksi & $13.8 \%$ & $3.5 \%$ & $2 \%$ & $0.3 \%$ & $0.5 \%$ \\
\hline Gunung Api Purba Nglanggeran & $11.8 \%$ & $4 \%$ & $2.5 \%$ & $1 \%$ & $0.8 \%$ \\
\hline Total & $43.6 \%$ & $27.3 \%$ & $14.3 \%$ & $4.5 \%$ & $10.8 \%$ \\
\hline
\end{tabular}

Tabel 3. Motivasi Berfoto Berdasarkan Obyek Foto Pemandangan Alam

\begin{tabular}{|c|c|c|c|c|c|}
\hline \multicolumn{2}{|c|}{ Obyek Alam yang Paling Menarik } & $\begin{array}{c}<\mathbf{1 7} \\
\text { tahun }\end{array}$ & $\begin{array}{l}\text { 18-30 } \\
\text { tahun }\end{array}$ & $\begin{array}{l}\text { 31-56 } \\
\text { tahun }\end{array}$ & Total \\
\hline $\begin{array}{ll}\text { Sangat } & \text { tidak } \\
\text { Setuju } & \end{array}$ & Malioboro & 1 & 2 & 0 & 3 \\
\hline & Hutan Pinus & 0 & 2 & 0 & 2 \\
\hline & Kalibiru & 0 & 1 & 0 & 1 \\
\hline & Tebing Breksi & 0 & 5 & 1 & 6 \\
\hline & $\begin{array}{lll}\text { Gunung } & \text { Api } & \text { Purba } \\
\text { Nglanggeran } & & \\
\end{array}$ & 1 & 2 & 0 & 3 \\
\hline & Total & 2 & 12 & 1 & 15 \\
\hline Tidak Setuju & Malioboro & 3 & 18 & & 21 \\
\hline 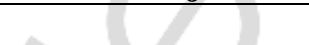 & Hutan Pinus & 0 & 1 & 0 & 1 \\
\hline $4+2$ & Kalibiru & 0 & 2 & 0 & 2 \\
\hline & $\begin{array}{lll}\text { Gunung } & \text { Api } & \text { Purba } \\
\text { Nglanggeran } & & \end{array}$ & 5 & 1 & & 6 \\
\hline 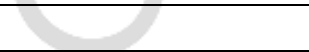 & Total & 8 & 22 & & 30 \\
\hline Ragu-ragu & Malioboro & 3 & 15 & & 18 \\
\hline & Kalibiru & 0 & 10 & & 10 \\
\hline
\end{tabular}




\begin{tabular}{|c|c|c|c|c|c|}
\hline \multicolumn{2}{|c|}{ Obyek Alam yang Paling Menarik } & \multirow{2}{*}{$\begin{array}{c}\begin{array}{c}<17 \\
\text { tahun }\end{array} \\
0\end{array}$} & \multirow{2}{*}{$\begin{array}{c}\begin{array}{c}\mathbf{1 8}-\mathbf{3 0} \\
\text { tahun }\end{array} \\
1\end{array}$} & \multirow[t]{2}{*}{$\begin{array}{l}31-56 \\
\text { tahun }\end{array}$} & \multirow{2}{*}{$\frac{\text { Total }}{1}$} \\
\hline & Tebing Breksi & & & & \\
\hline & $\begin{array}{lll}\text { Gunung } & \text { Api } & \text { Purba } \\
\text { Nglanggeran } & & \end{array}$ & 0 & 7 & & 7 \\
\hline & Total & 3 & 33 & 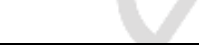 & 36 \\
\hline \multirow[t]{6}{*}{ Setuju } & Malioboro & 3 & 27 & 3 & 33 \\
\hline & Hutan Pinus & 4 & 40 & $3-2$ & 47 \\
\hline & Kalibiru & 1 & 43 & 6 & 50 \\
\hline & Tebing Breksi & 1 & 35 & 3 & 39 \\
\hline & $\begin{array}{lll}\text { Gunung } & \text { Api } & \text { Purba } \\
\text { Nglanggeran } & & \end{array}$ & 1 & 31 & 0 & 32 \\
\hline & Total & 10 & 176 & 15 & 201 \\
\hline \multirow[t]{6}{*}{ Sangat Setuju } & Malioboro & 2 & 3 & 0 & 5 \\
\hline & Hutan Pinus & 3 & 24 & 3 & 30 \\
\hline & Kalibiru & 0 & 14 & 3 & 17 \\
\hline & Tebing Breksi & 4 & 26 & 4 & 34 \\
\hline & $\begin{array}{lll}\text { Gunung } & \text { Api } & \text { Purba } \\
\text { Nglanggeran }\end{array}$ & 4 & 26 & 2 & 32 \\
\hline & Total & 13 & 93 & 12 & 118 \\
\hline
\end{tabular}

Tabel 4. Motivasi Berfoto Berdasarkan Kondisi dan Kelengkapan Fasilitas

\begin{tabular}{|c|c|c|c|c|c|}
\hline \multicolumn{2}{|c|}{ Kondisi dan Kelengkapan Fasilitas } & \multirow{2}{*}{$\begin{array}{c}<17 \\
\text { tahun }\end{array}$} & \multirow{2}{*}{$\begin{array}{c}\begin{array}{c}18-30 \\
\text { tahun }\end{array} \\
1\end{array}$} & \multirow[t]{2}{*}{$\begin{array}{l}31-56 \\
\text { tahun }\end{array}$} & \multirow{2}{*}{$\begin{array}{c}\text { Total } \\
1\end{array}$} \\
\hline $\begin{array}{ll}\text { Sangat } & \text { tidak } \\
\text { Setuju } & \end{array}$ & Hutan Pinus & & & & \\
\hline & $\begin{array}{lll}\text { Gunung } & \text { Api } & \text { Purba } \\
\text { Nglanggeran }\end{array}$ & & 1 & & 1 \\
\hline & 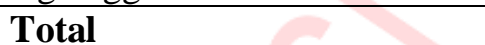 & & 2 & & 2 \\
\hline Tidak Setuju & Malioboro & 0 & 2 & 0 & 2 \\
\hline & Hutan Pinus & 0 & 3 & 1 & 4 \\
\hline & Tebing Breksi & 0 & 5 & 0 & 5 \\
\hline & $\begin{array}{l}\text { Gunung Api } \quad \text { Purba } \\
\text { Nglanggeran }\end{array}$ & 1 & 4 & 0 & 5 \\
\hline & Total & 1 & 14 & 1 & 16 \\
\hline Ragu-ragu & Malioboro & 6 & 15 & 0 & 21 \\
\hline & Hutan Pinus & 0 & 8 & 1 & 9 \\
\hline & Kalibiru & 0 & 16 & 3 & 19 \\
\hline & Tebing Breksi & 0 & 14 & 1 & 15 \\
\hline & $\begin{array}{lll}\text { Gunung } & \text { Api } & \text { Purba } \\
\text { Nglanggeran } & & \\
\end{array}$ & 0 & 15 & 1 & 16 \\
\hline & Total & 6 & 68 & 6 & 80 \\
\hline Setuju & Malioboro & 5 & 43 & 3 & 51 \\
\hline 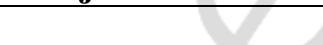 & Hutan Pinus & 4 & 44 & 2 & 50 \\
\hline 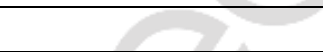 & Kalibiru & 1 & 44 & 4 & 49 \\
\hline 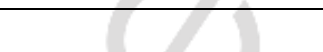 & Tebing Breksi & 3 & 36 & 6 & 45 \\
\hline & $\begin{array}{lll}\text { Gunung } & \text { Api } & \text { Purba } \\
\text { Nglanggeran } & & \end{array}$ & 4 & 40 & 1 & 45 \\
\hline 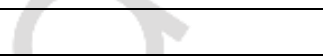 & Total & 17 & 207 & 16 & 240 \\
\hline Sangat Setuju & Malioboro & 1 & 5 & 0 & 6 \\
\hline & Hutan Pinus & 3 & 11 & 2 & 16 \\
\hline & Kalibiru & 0 & 10 & 2 & 12 \\
\hline
\end{tabular}




\begin{tabular}{|l|l|c|c|c|c|}
\hline \multicolumn{2}{|c|}{ Kondisi dan Kelengkapan Fasilitas } & $\begin{array}{c}<\mathbf{1 7} \\
\text { tahun }\end{array}$ & $\begin{array}{c}\mathbf{1 8}-\mathbf{3 0} \\
\text { tahun }\end{array}$ & $\begin{array}{c}\mathbf{3 1 - 5 6} \\
\text { tahun }\end{array}$ & Total \\
\hline & Tebing Breksi Api Purba & 2 & 12 & 1 & 15 \\
\hline $\begin{array}{l}\text { Gunung Aglanggeran } \\
\text { Nglat }\end{array}$ & 6 & 7 & 0 & 13 \\
\hline & $\mathbf{1 2}$ & $\mathbf{4 5}$ & $\mathbf{5}$ & $\mathbf{6 2}$ \\
\hline
\end{tabular}

Tabel 5. Kemudahan dalam Menemukan Lokasi Berfoto

\begin{tabular}{|l|c|c|c|c|c|}
\hline \multirow{2}{*}{ Obyek Wisata } & \multicolumn{4}{|c|}{ Kemudahan dalam Menemukan Lokasi Berfoto } \\
\cline { 2 - 6 } & $\begin{array}{c}\text { Sangat Tidak } \\
\text { Setuju }\end{array}$ & $\begin{array}{c}\text { Tidak } \\
\text { Setuju }\end{array}$ & $\begin{array}{c}\text { Ragu- } \\
\text { Ragu }\end{array}$ & Setuju & $\begin{array}{c}\text { Sangat } \\
\text { Setuju }\end{array}$ \\
\hline Malioboro & 0 & 0 & 22 & 43 & 15 \\
\hline Hutan Pinus & 1 & 1 & 3 & 57 & 18 \\
\hline Kalibiru & 0 & 0 & 6 & 39 & 35 \\
\hline Tebing breksi & 0 & 3 & 10 & 54 & 13 \\
\hline $\begin{array}{l}\text { Gunung Api Purba } \\
\text { Nglanggeran }\end{array}$ & 0 & 0 & 9 & 56 & 15 \\
\hline Total & $\mathbf{1}$ & $\mathbf{4}$ & $\mathbf{5 0}$ & $\mathbf{2 4 9}$ & $\mathbf{9 6}$ \\
\hline
\end{tabular}

Tabel 6. Kemudahan Akses Pasca Berfoto

\begin{tabular}{|l|c|c|c|c|c|}
\hline \multirow{2}{*}{ Obyek Wisata } & \multicolumn{5}{c|}{ Kemudahan Akses Pasca Berfoto } \\
\cline { 2 - 6 } & $\begin{array}{c}\text { Sangat Tidak } \\
\text { Setuju }\end{array}$ & $\begin{array}{c}\text { Tidak } \\
\text { Setuju }\end{array}$ & $\begin{array}{c}\text { Ragu- } \\
\text { Ragu }\end{array}$ & Setuju & $\begin{array}{c}\text { Sangat } \\
\text { Setuju }\end{array}$ \\
\hline Malioboro & 0 & 4 & 13 & 43 & 20 \\
\hline Hutan Pinus & 2 & 7 & 19 & 40 & 12 \\
\hline Kalibiru & 0 & 0 & 3 & 51 & 26 \\
\hline Tebing breksi & 0 & 7 & 31 & 35 & 7 \\
\hline Gunung Api Purba Nglanggeran & 7 & 29 & 25 & 17 & 2 \\
\hline Total & $\mathbf{9}$ & $\mathbf{4 7}$ & $\mathbf{9 1}$ & $\mathbf{1 8 6}$ & $\mathbf{6 7}$ \\
\hline
\end{tabular}

Tabel 7. Perilaku Edit Foto

\begin{tabular}{|c|c|c|c|c|c|c|}
\hline \multirow{2}{*}{ Rentang Umur } & \multicolumn{5}{|c|}{ Perilaku Edit Foto } & \multirow{2}{*}{ Tot } \\
\cline { 2 - 7 } & $\begin{array}{c}\text { Sangat } \\
\text { Tidak Setuju }\end{array}$ & $\begin{array}{c}\text { Tidak } \\
\text { Setuju }\end{array}$ & $\begin{array}{c}\text { Ragu- } \\
\text { Ragu }\end{array}$ & Setuju & $\begin{array}{c}\text { Sangat } \\
\text { Setuju }\end{array}$ & \\
\hline$<17$ tahun & 0 & 4 & 5 & 23 & 4 & $\mathbf{3 6}$ \\
\hline $18-30$ tahun & 9 & 48 & 64 & 187 & 28 & $\mathbf{3 3 6}$ \\
\hline $31-56$ tahun & 1 & 5 & 11 & 8 & 3 & $\mathbf{2 8}$ \\
\hline Total & $\mathbf{1 0}$ & $\mathbf{5 7}$ & $\mathbf{8 0}$ & $\mathbf{2 1 8}$ & $\mathbf{3 5}$ & $\mathbf{4 0 0}$ \\
\hline
\end{tabular}

Tabel 8. Perilaku Publish Setelah Mendapatkan Foto

\begin{tabular}{|c|c|c|c|c|c|c|}
\hline \multirow{2}{*}{ Rentang Umur } & \multicolumn{5}{|c|}{ Perilaku Publish Setelah Mendapat Foto } & \multirow[b]{2}{*}{ Tot } \\
\hline & $\begin{array}{c}\text { Sangat } \\
\text { Tidak Setuju } \\
\end{array}$ & $\begin{array}{l}\text { Tidak } \\
\text { Setuju }\end{array}$ & $\begin{array}{l}\text { Ragu- } \\
\text { Ragu }\end{array}$ & Setuju & $\begin{array}{l}\text { Sangat } \\
\text { Setuju }\end{array}$ & \\
\hline$<17$ tahun & 0 & 2 & 8 & 23 & 3 & 36 \\
\hline $18-30$ tahun & 7 & 43 & 68 & 174 & 44 & 336 \\
\hline $31-56$ tahun & 1 & 2 & 10 & 15 & 0 & 28 \\
\hline Total & 8 & 47 & 86 & 212 & 47 & 400 \\
\hline
\end{tabular}


Tabel 9. Preferensi Penggunaan Instagram

\begin{tabular}{|c|c|c|c|c|c|c|}
\hline \multirow{2}{*}{ Umur } & \multicolumn{5}{|c|}{ Preferensi Penggunaan Instagram } & \multirow{2}{*}{ Total } \\
\cline { 2 - 6 } & $\begin{array}{c}\text { Sangat Tidak } \\
\text { Setuju }\end{array}$ & $\begin{array}{c}\text { Tidak } \\
\text { setuju }\end{array}$ & $\begin{array}{c}\text { Ragu- } \\
\text { ragu }\end{array}$ & Setuju & $\begin{array}{c}\text { Sangat } \\
\text { setuju }\end{array}$ & \\
\hline$<17$ tahun & 1 & 2 & 5 & 14 & 14 & $\mathbf{3 6}$ \\
\hline $18-30$ tahun & 4 & 28 & 37 & 174 & 93 & $\mathbf{3 3 6}$ \\
\hline $31-56$ tahun & 0 & 2 & 8 & 12 & 6 & $\mathbf{2 8}$ \\
\hline Total & $\mathbf{5}$ & $\mathbf{3 2}$ & $\mathbf{5 0}$ & $\mathbf{2 0 0}$ & $\mathbf{1 1 3}$ & $\mathbf{4 0 0}$ \\
\hline
\end{tabular}

Tabel 10. Alasan Berfoto

\begin{tabular}{|l|c|c|c|c|}
\hline \multirow{2}{*}{\multicolumn{1}{|c|}{ Alasan Berfoto }} & \multicolumn{3}{c|}{ Umur } & \multirow{2}{*}{ Total } \\
\cline { 2 - 4 } & $<\mathbf{1 7}$ tahun & $\mathbf{1 8 - 3 0}$ tahun & $\mathbf{3 1 - 5 6}$ tahun & \\
\hline Ingin mendapat kenangan berharga & 13 & 125 & 12 & $\mathbf{1 5 0}$ \\
\hline Ingin mengabadikan keindahan alam & 16 & 164 & 13 & $\mathbf{1 9 3}$ \\
\hline Ingin pamer/narsis kepada orang lain & 2 & 25 & 2 & $\mathbf{2 9}$ \\
\hline $\begin{array}{l}\text { Ingin memperoleh pujian/sanjungan dari } \\
\text { orang lain }\end{array}$ & 5 & 22 & 1 & $\mathbf{2 8}$ \\
\hline Total & $\mathbf{3 6}$ & $\mathbf{3 3 7}$ & $\mathbf{2 8}$ & $\mathbf{4 0 0}$ \\
\hline
\end{tabular}

Tabel 11. Pengaruh Banyaknya Spot Foto terhadap Kebahagiaan Wisatawan

\begin{tabular}{|c|c|c|c|c|c|}
\hline \multicolumn{2}{|c|}{$\begin{array}{c}\text { Banyaknya Spot Foto terhadap Kebahagiaan } \\
\text { Wisatawan }\end{array}$} & \multirow{2}{*}{$\begin{array}{c}\begin{array}{c}<17 \\
\text { tahun }\end{array} \\
0\end{array}$} & \multirow{2}{*}{$\begin{array}{c}\begin{array}{c}\text { 18-30 } \\
\text { tahun }\end{array} \\
1\end{array}$} & \multirow[t]{2}{*}{$\begin{array}{l}31-56 \\
\text { tahun }\end{array}$} & \multirow{2}{*}{ 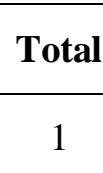 } \\
\hline $\begin{array}{l}\text { Sangat Tidak } \\
\text { Setuju }\end{array}$ & Malioboro & & & & \\
\hline & Tebing breksi & 0 & 1 & & 1 \\
\hline & $\begin{array}{l}\text { Gunung Api Purba } \\
\text { Nglanggeran }\end{array}$ & 2 & 2 & & 4 \\
\hline & 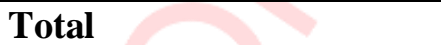 & 2 & 4 & & 6 \\
\hline \multirow[t]{5}{*}{ Tidak Setuju } & Malioboro & 0 & 2 & 1 & 3 \\
\hline & Hutan Pinus & 0 & 7 & 0 & 7 \\
\hline & Tebing breksi & 0 & 2 & 0 & 2 \\
\hline & $\begin{array}{l}\text { Gunung Api Purba } \\
\text { Nglanggeran }\end{array}$ & 1 & 8 & 0 & 9 \\
\hline & Total & $\mathbf{1}$ & 19 & $\mathbf{1}$ & 21 \\
\hline \multirow[t]{6}{*}{ Ragu-Ragu } & Malioboro & 2 & 11 & 0 & 13 \\
\hline & Hutan Pinus & 1 & 3 & 0 & 4 \\
\hline & Kalibiru & 0 & 2 & 0 & 2 \\
\hline & Tebing breksi & 0 & 7 & 0 & 7 \\
\hline & $\begin{array}{l}\text { Gunung Api Purba } \\
\text { Nglanggeran }\end{array}$ & 1 & 11 & 1 & 13 \\
\hline & Total & 4 & 34 & 1 & 39 \\
\hline Setuju & Malioboro & 6 & 34 & 1 & 41 \\
\hline 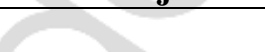 & Hutan Pinus & 5 & 41 & 6 & 52 \\
\hline 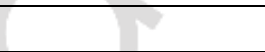 & Kalibiru & 0 & 39 & 7 & 46 \\
\hline \multirow[t]{2}{*}{+2} & Tebing breksi & 1 & 40 & 6 & 47 \\
\hline & $\begin{array}{l}\text { Gunung Api Purba } \\
\text { Nglanggeran }\end{array}$ & 4 & 41 & 0 & 45 \\
\hline
\end{tabular}




\begin{tabular}{|c|l|c|c|c|c|}
\hline \multicolumn{2}{|c|}{$\begin{array}{c}\text { Banyaknya Spot Foto terhadap Kebahagiaan } \\
\text { Wisatawan }\end{array}$} & $\begin{array}{c}<\mathbf{1 7} \\
\text { tahun }\end{array}$ & $\begin{array}{c}\mathbf{1 8}-\mathbf{3 0} \\
\text { tahun }\end{array}$ & $\begin{array}{c}\mathbf{3 1 - 5 6} \\
\text { tahun }\end{array}$ & Total \\
\hline & Total & $\mathbf{1 6}$ & $\mathbf{1 9 5}$ & $\mathbf{2 0}$ & $\mathbf{2 3 1}$ \\
\hline Sangat Setuju & Malioboro & 4 & 17 & 1 & 22 \\
\hline & Hutan Pinus & 1 & 16 & 0 & 17 \\
\hline & Kalibiru & 1 & 29 & 2 & 32 \\
\hline & Tebing breksi & 4 & 17 & 2 & 23 \\
\hline & $\begin{array}{l}\text { Gunung Api Purba } \\
\text { Nglanggeran }\end{array}$ & 3 & 5 & 1 & 9 \\
\hline & Total & $\mathbf{1 3}$ & $\mathbf{8 4}$ & $\mathbf{6}$ & $\mathbf{1 0 3}$ \\
\hline
\end{tabular}

Tabel 12. Aktifitas Berfoto terhadap Kebahagiaan

\begin{tabular}{|c|c|c|c|c|c|c|}
\hline \multirow{2}{*}{ Umur } & \multicolumn{5}{|c|}{ Aktifitas Berfoto terhadap Kebahagiaan } & \multirow{2}{*}{ Total } \\
\cline { 2 - 6 } & Sangat tidak setuju & Tidak setuju & $\begin{array}{c}\text { Ragu- } \\
\text { ragu }\end{array}$ & Setuju & Sangat setuju & \\
\hline$<17$ tahun & 1 & 0 & 3 & 21 & 11 & $\mathbf{3 6}$ \\
\hline $18-30$ tahun & 2 & 20 & 35 & 196 & 83 & $\mathbf{3 3 6}$ \\
\hline $31-56$ tahun & 0 & 1 & 1 & 18 & 8 & $\mathbf{2 8}$ \\
\hline Total & $\mathbf{3}$ & $\mathbf{2 1}$ & $\mathbf{3 9}$ & $\mathbf{2 3 5}$ & $\mathbf{1 0 2}$ & $\mathbf{4 0 0}$ \\
\hline
\end{tabular}

Tabel 13. Aktifitas Pengambilan Foto

\begin{tabular}{|l|c|c|c|c|c|c|}
\hline \multirow{2}{*}{ Umur } & \multicolumn{5}{|c|}{ Aktifitas Pengambilan Foto } & \multirow{2}{*}{ Total } \\
\cline { 2 - 6 } & $\begin{array}{c}\text { Sangat tidak } \\
\text { setuju }\end{array}$ & $\begin{array}{c}\text { Tidak } \\
\text { setuju }\end{array}$ & $\begin{array}{c}\text { Ragu- } \\
\text { ragu }\end{array}$ & Setuju & Sangat setuju & \\
\hline$<17$ tahun & 0 & 0 & 2 & 23 & 11 & $\mathbf{3 6}$ \\
\hline $18-30$ tahun & 3 & 15 & 28 & 202 & 88 & $\mathbf{3 3 6}$ \\
\hline $31-56$ tahun & 0 & 0 & 0 & 19 & 9 & $\mathbf{2 8}$ \\
\hline Total & $\mathbf{3}$ & $\mathbf{1 5}$ & $\mathbf{3 0}$ & $\mathbf{2 4 4}$ & $\mathbf{1 0 8}$ & $\mathbf{4 0 0}$ \\
\hline
\end{tabular}

Tabel 14. Kuantitas Foto Menentukan Perasaan Bahagia

\begin{tabular}{|c|c|c|c|c|c|c|}
\hline \multirow{2}{*}{ Umur } & \multicolumn{5}{|c|}{ Kuantitas Foto Mentukan Perasaan Bahagia } & \multirow{2}{*}{ Total } \\
\cline { 2 - 6 } & $\begin{array}{c}\text { Sangat tidak } \\
\text { setuju }\end{array}$ & $\begin{array}{c}\text { Tidak } \\
\text { setuju }\end{array}$ & Ragu-ragu & Setuju & Sangat setuju & \\
\hline$<17$ tahun & 0 & 1 & 3 & 18 & 14 & $\mathbf{3 6}$ \\
\hline $18-30$ tahun & 1 & 21 & 34 & 185 & 95 & $\mathbf{3 3 6}$ \\
\hline $31-56$ tahun & 0 & 2 & 1 & 13 & 12 & $\mathbf{2 8}$ \\
\hline Total & $\mathbf{1}$ & $\mathbf{2 4}$ & $\mathbf{3 8}$ & $\mathbf{2 1 6}$ & $\mathbf{1 2 1}$ & $\mathbf{4 0 0}$ \\
\hline
\end{tabular}

Tabel 15. Kualitas Foto Menentukan Perasaan Bahagia

\begin{tabular}{|l|c|c|c|c|c|c|}
\hline \multirow{2}{*}{ Umur } & \multicolumn{4}{|c|}{ Kualitas Foto Menentukan Perasaan Bahagia } & \multirow{2}{*}{ Total } \\
\cline { 2 - 6 } & $\begin{array}{c}\text { Sangat tidak } \\
\text { setuju }\end{array}$ & $\begin{array}{c}\text { Tidak } \\
\text { setuju }\end{array}$ & Ragu-ragu & Setuju & $\begin{array}{c}\text { Sangat } \\
\text { setuju }\end{array}$ & \\
\hline$<17$ tahun & 0 & 1 & 3 & 18 & 14 & $\mathbf{3 6}$ \\
\hline
\end{tabular}




\begin{tabular}{|c|c|c|c|c|c|c|}
\hline \multirow[b]{2}{*}{ Umur } & \multicolumn{5}{|c|}{ Kualitas Foto Menentukan Perasaan Bahagia } & \multirow[b]{2}{*}{ Total } \\
\hline & $\begin{array}{c}\text { Sangat tidak } \\
\text { setuju }\end{array}$ & $\begin{array}{l}\text { Tidak } \\
\text { setuju }\end{array}$ & Ragu-ragu & Setuju & $\begin{array}{l}\text { Sangat } \\
\text { setuju }\end{array}$ & \\
\hline 18-30 tahun & 1 & 5 & 24 & 207 & 99 & 336 \\
\hline 31-56 tahun & 0 & 1 & 2 & 15 & 10 & 28 \\
\hline Total & 1 & 7 & 29 & 240 & 123 & 400 \\
\hline
\end{tabular}

